\title{
Nursing diagnoses in primary health care consultations to newborns
}

\author{
Diagnósticos de enfermagem em consultas de atenção primária à saúde de recém-nascidos \\ Diagnósticos de enfermería en las consultas de atención primaria de salud de recién nacidos
}

\section{Priscila Costa', Amanda Pereira Duarte', Aline Santa Cruz Belela-Anacleto', Paula Rosenberg de Andrade", Maria Magda Ferreira Gomes Balieiro', Maria De La Ó Ramallo Veríssimo"'I \\ ' Universidade Federal de São Paulo, Paulista School of Nursing. São Paulo, São Paulo, Brazil. \\ "Centro Assistencial Cruz de Malta. São Paulo, São Paulo, Brazil. \\ II' Universidade de São Paulo, School of Nursing. São Paulo, São Paulo, Brazil.}

How to cite this article:

Costa P, Duarte AP, Belela-Anacleto ASC, Andrade PR, Balieiro MMFG, Veríssimo MDLOR.

Nursing diagnoses in primary health care consultations to newborns. Rev Bras Enferm [Internet]. 2018;71(6):2961-8.

DOI: http://dx.doi.org/10.1590/0034-7167-2017-0954

Submission: 02-07-2018 Approval: 04-21-2018

\section{ABSTRACT}

Objective: To describe and analyze nursing diagnoses established on newborns' medical consultations in a primary health care service. Method: Descriptive, analytical and quantitative study performed in a primary health care clinic in São Paulo. Data were collected from the medical records of 37 children treated in 39 nursing consultations during their neonatal period. The identified nursing diagnoses were analyzed regarding: frequency, classification in strengthening or exhaustion in light of the health-disease process, and the correspondence with the essential needs of infants. Results: 372 diagnoses were identified, most of them of strengthening $(71 \%)$, such as efficient development $(n=37)$ and effective growth $(n=36)$. Among the exhaustion diagnoses $(29 \%)$, there was a predominance of risk for suffocation ( $n=15)$ and impaired tissue integrity $(n=14)$. Most diagnoses corresponded to the need of physical protection and security. Conclusion: Families are strengthened in the care of the essential needs of newborns, however, preventing diseases is necessary. Descriptors: Nursing Diagnosis; Primary Health Care; Infant, Newborn; Child Development; Health Promotion.

\section{RESUMO}

Objetivo: Descrever e analisar os diagnósticos de enfermagem estabelecidos em consultas de recém-nascidos num serviço de atenção primária à saúde. Método: Estudo descritivo, analítico e quantitativo realizado num ambulatório de atenção primária à saúde em São Paulo. Os dados foram coletados nos prontuários de 37 crianças atendidas em 39 consultas de enfermagem no período neonatal. Os diagnósticos de enfermagem identificados foram analisados quanto a: frequência, classificação em fortalecimento ou desgaste frente ao processo saúde-doença, e correspondência com as necessidades essenciais das crianças. Resultados: Foram identificados 372 diagnósticos, sendo a maioria de fortalecimento $(71 \%)$, como os de desenvolvimento eficaz $(n=37)$ e de crescimento eficaz $(n=36)$. Entre os diagnósticos de desgaste $(29 \%)$ predominaram risco de sufocação $(n=15)$ e integridade da pele prejudicada $(\mathrm{n}=14)$. A maioria dos diagnósticos correspondeu à necessidade de proteção física e de segurança. Conclusão: As famílias estão fortalecidas na atenção às necessidades essenciais do recém-nascido, porém a prevenção de agravos se faz necessária.

Descritores: Diagnóstico de Enfermagem; Atenção Primária à Saúde; Recém-Nascido; Desenvolvimento Infantil; Promoção da Saúde.

\section{RESUMEN}

Objetivo: Describir y analizar los diagnósticos de enfermería establecidos en consultas de recién nacidos en un servicio de atención primaria de salud. Método: Estudio descriptivo, analítico y cuantitativo realizado en un ambulatorio de atención primaria de salud en São Paulo. Los datos fueron recolectados en los prontuarios de 37 niños atendidos en 39 consultas de enfermería en el período neonatal. Los diagnósticos de enfermería identificados fueron analizados en cuanto a: la frecuencia, la clasificación en fortalecimiento o desgaste frente al proceso salud-enfermedad, y la correspondencia con las necesidades esenciales de los niños. Resultados: Se identificaron 372 diagnósticos, siendo la mayoría de fortalecimiento $(71 \%)$, como los de desarrollo eficaz $(\mathrm{n}=37)$ y de crecimiento eficaz $(n=36)$. Entre los diagnósticos de desgaste $(29 \%)$, predominaron el riesgo de asfixia $(n=15)$ y la integridad de la piel perjudicada 
$(n=14)$. La mayoría de los diagnósticos correspondió a la necesidad de protección física y seguridad. Conclusión: Las familias están fortalecidas en la atención a las necesidades esenciales del recién nacido, pero la prevención de agravios se hace necesaria.

Descriptores: Diagnóstico de Enfermería; Atención Primaria de Salud; Recién Nacido; Desarrollo Infantil; Promoción de la Salud.

\section{CORRESPONDING AUTHOR Priscila Costa E-mail: priscila.costa@unifesp.br}

\section{INTRODUCTION}

The neonatal period represents a vulnerable phase for the survival of an infant ${ }^{(1)}$. Worldwide, it is estimated that 2.9 million deaths occur in the first 28 days of life, mainly due to infections, intrapartum conditions and premature birth complications ${ }^{(2)}$. In Brazil, the rate of neonatal mortality represents from $60 \%$ to $70 \%$ of child mortality, and perinatal diseases and congenital malformations are its main causes ${ }^{(3)}$. Thus, the Ministry of Health recommends that primary health care professionals perform the first consultation of newborns and their families or a home visit in the first week of the child's life ${ }^{(4)}$.

Nursing consultation represents an important strategy for the strengthening of family care in promoting integral newborn development. Its objectives include monitoring growth and development, supporting exclusive breastfeeding, verifying neonatal screening and child's immunization, family orientation to identify signs of illness and to seek emergency services, promoting safe environments and affective care in order to build a bond between parents and newborns, among others ${ }^{(4)}$.

As an activity incorporated to primary health care actions, nursing consultation must be systematically performed according to the nursing process, contemplating the stages of data assessment (history), diagnosis, planning, implementation and evaluation. Nursing diagnosis represents the interpretation and grouping process of the data collected from the assessment and expressed the answers of individuals, families or human collectivity in a given moment of the health-disease process ${ }^{(5)}$.

Considering that determinants and constraints of the healthdisease process in newborns include the families' ways of working and living, identifying newborn diagnoses in childcare consultations contribute to recognize the potential strengthening and wastage in view of the health-disease process, as well as to understand the individuals as historical, social and political subjects, articulated with the family, environment and society context in which they are inserted ${ }^{(6)}$.

However, understanding newborns' needs also requires the support of theoretical references adequate to the specificities of the subject in development ${ }^{(7)}$. In this sense, Brazelton and Greenspan's benchmark of the irreducible needs of children ${ }^{(8-9)}$ can support the interpretation of diagnoses in order to capture the needs of newborns attended to in primary health care consultations. The irreducible needs of children are the foundation to establish experiences and fundamental care around which families, education, care, social security, legal and health systems must organize themselves ${ }^{(7-9)}$.

Evidence that support nursing care with newborns in primary health care are essential, however, there are few studies ${ }^{(10-12)}$ on nursing diagnoses in newborns' health care follow-ups in primary health care.

\section{OBJECTIVE}

To describe and analyze nursing diagnoses established in newborn consultations in a primary health care service.

\section{METHOD}

\section{Ethical aspects}

The study development complied with national and international ethical standards with research with human beings. The research project was approved by the Research Ethics Committee of the Federal University of São Paulo and authorized by the institution.

\section{Study design, location and period}

This is a descriptive and analytical study, with quantitative approach, conducted in an outpatient health care center of philanthropic character, and its operating structure corresponds to a basic health unit.

The outpatient clinic provides primary health care services, offering health follow-up appointments performed by nurses, doctors, nutritionists, psychologists, social workers, pharmacists and dentists, mostly for children, adolescents and women, in addition to routine laboratory examinations, pharmacy, immunization, drug administration and curatives. It is located in the southwestern region of Jabaquara, in the city of São Paulo - a region that has high social vulnerability levels, with 5,999 households in a situation of high vulnerability and 7,330 households with per capita income of up to 0.5 minimum wage ${ }^{(13)}$.

To decrease the chance of bias, data were collected by two members of the research team, from January to July 2017. The two researchers verified, independently, the records of nursing consultations in newborns' charts, filling an instrument specifically elaborated for this study. The data extracted, doubly checked, referred to clinical and sociodemographic variables of newborns and their families, and to the nursing diagnoses of each consultation.

\section{Population, inclusion and exclusion criteria}

Participants were selected from the list of nursing consultations conducted in the service, from January to December 2016, which totalized approximately 170 childcare consultations. Such consultations were conducted, mainly, by the nurse of the service, who is a PhD and specialist in pediatric nursing, that has been working for 20 years in the health service mentioned, or by neonatology nursing residents, under supervision of professors specialized in pediatric nursing of a public federal university in São Paulo.

The inclusion and exclusion criteria were: newborns aged from 1 and 28 days old at the time of the consultation and assisted 
in a nursing consultation in 2016. The exclusion criterion was the absence of chart records regarding nursing diagnoses.

After analyzing the records of the 170 nursing consultations from 2016, 39 were included in the study because they were newborn consultations. Since all had at least one nursing diagnosis, none were excluded from the study.

\section{Study protocol}

The studied variables referred to clinical and sociodemographic characteristics of newborns and their families, and to nursing diagnoses. Regarding newborns, these variables included: gender, full term birth (gestational age $\geq 37$ weeks), low birth weight $(<2,500 \mathrm{~g})$, type of delivery, hospitalization during the neonatal period, chronological age at the time of consultation (days or weeks of life) and household composition.

The diagnoses referred to the registers formulated by the professional in the consultation, being extracted exactly as they were in the patients' chart. Since 2015, nomenclatures from the International Classification for Nursing Practice (ICNP, 2015 version, Brazilian Portuguese) have been used, in order to standardize the language system adopted in diagnoses formulation, as well as to improve technical-scientific knowledge of nurses and professors that perform the consultation in the mentioned service.

\section{Results analysis and statistics}

Considering that promoting child health care in the perspective of collective health means to reduce health vulnerabilities and risks related to determinants and constraints ${ }^{(14)}$ of the healthdisease process, the identified nursing diagnoses were analyzed and classified in strengthening or wastage nursing diagnoses in view of this process ${ }^{(15)}$. The diagnoses of strengthening in view of the mentioned process represent normality and present judgements such as "effective", "suitable" and "normal". The ones related to wastage in view of the health-disease process represent abnormalities or risk for damage and are composed of judgement terms such as "damaged", "stopped" and "altered".

The nursing diagnoses were also analyzed according to Brazelton and Greenspan's frame of reference of irreducible needs of children ${ }^{(8-9)}$. These needs are related to the survival and development of individuals, regardless of ethnic origin, social class, physical or mental condition ${ }^{(8-9)}$. The authors define six sets of irreducible needs: ongoing nurturing relationships; physical protection, safety and regulation; experiences tailored to individual differences, developmentally appropriate experiences; limit setting, structure, and expectations; and stable, supportive communities, and cultural continuity. The choice of this frame of reference is justified by its fitness to child development process in a comprehensive perspective of human development, which considers the interactive processes of children with their environment ${ }^{(7)}$. As such reference was not elaborated in the perspective of nursing care, another text was used on a nursing care proposal according to the irreducible needs for this diagnosis classification ${ }^{(16)}$.

Data were tabulated in an Excel spreadsheet and analyzed in the Epi Info 7 software. Categorical variables are presented according to absolute and relative frequencies, and the numeric variables according to descriptive statistics with mean, standard deviation, maximum and minimum values. The bivariate analysis was conducted to verify the association between clinical and sociodemographic characteristics of the newborn and the occurrence of nursing diagnoses of wastage in view of the health-disease process. For this, the Student's t-test was applied for continuous variables, and the chi-squared test or Fisher's exact test were applied for the categorical variables, with a confidence interval of $95 \%$ and significance level of $5 \%$.

\section{RESULTS}

In 2016, 37 newborns were assisted in 39 nursing consultations. The newborns were from 1 to 27 days old, with an average of 15 days and mode of 10 days of life. Most of them were male $(51.3 \%)$, born at term $(88.6 \%)$, with normal childbirth $(67.6 \%)$, without low birth weight $(96.7 \%)$, and without hospitalization in the neonatal period $(87.9 \%)$.

It was observed that most newborns' families was composed of the parents and their biological children (58.3\%); 30.6\% of at least one parent, one or more children and one or more family member, related or not (grandparents, uncle, stepmother or stepfather); and $11.1 \%$ of the families was composed of only one parent, who was the mother of the child in all cases.

The ICNP nomenclature was the most used to formulate the diagnoses or the focuses of practice. In total, 372 diagnoses were formulated in the 39 consultations, with an average of 9.5 diagnoses per consultation. This total was composed by 48 diagnostic statements, and 17 of them were of strengthening and 31 of wastage in view of the health-disease process.

The strengthening nursing diagnoses regarding the healthdisease process were more frequent $(70.9 \%)$, as shown in Table 1 , when compared to wastage nursing diagnoses $(29.1 \%)$.

In Table 1, it can be observed that all children had the diagnosis of effective newborn development, and more than $97 \%$ of effective growth. Most of the strengthening diagnoses regarding the health-disease process was related to the need for physical protection and safety, and two diagnoses represented the meeting of the need for ongoing nurturing relationships.

Wastage nursing diagnoses appeared less frequently, reaching a maximum of $40.5 \%$ children (Table 2). However, there was a higher number of diagnostic titles in this group, showing variability in situations of risk or vulnerability perceived by nurses.

In the analysis of nursing diagnoses according to the frame of reference of the irreducible needs of children, it was verified that the most part corresponded to the need of physical protection and safety (Table 1 and 2). In this need, the diagnoses were relative to the promotion and maintenance of body integrity, and the prevention and treatment of diseases, including: breastfeeding, immunization, sunbathing, sleeping, body hygiene, evacuation and colic, breathing, cutaneous, infectious disorders, insufficient weight gain and nutritional risk.

The irreducible need of ongoing nurturing relationships was the second most contemplated need, with diagnoses relative to the interactions between family members and the newborn, to the bond building, competences and difficulties of relatives to exercise their parental role, as well as possible modifications in the dynamic or on family processes due to the arrival of a new member. 
Table 1 - Strengthening nursing diagnoses in view of the health-disease process according to the irreducible needs of children that correspond to it, São Paulo, Brazil, 2016

\begin{tabular}{lccc}
\hline $\begin{array}{l}\text { Nursing diagnoses indicating strengthening in } \\
\text { view of the health-disease process }\end{array}$ & $\begin{array}{c}\text { Frequency } \\
\text { of the } \\
\text { diagnosis (n) }\end{array}$ & $\begin{array}{c}\text { \% of the } \\
\text { diagnosis } \\
\text { in total }\end{array}$ & $\begin{array}{c}\text { \% of children } \\
\text { with the } \\
\text { diagnosis }\end{array}$ \\
\hline $\begin{array}{l}\text { Need for physical and safety protection } \\
\quad \text { Effective newborn development }\end{array}$ & 37 & 14.0 & 100.0 \\
$\quad$ Effective growth & 36 & 13.6 & 97.3 \\
$\quad$ Effective evacuation & 31 & 12.5 & 89.2 \\
Adequate sleep & 28 & 11.7 & 83.8 \\
Exclusive breastfeeding & 26 & 10.6 & 75.7 \\
Adherence to immunization regime & 11 & 4.9 & 70.3 \\
$\quad$ Adherence to supplementation regime & 9 & 3.4 & 29.7 \\
$\quad$ Proper hygiene & 7 & 2.7 & 18.9 \\
$\quad$ Adherence to therapeutic regime (sunbathing) & 3 & 1.1 & 8.1 \\
$\quad$ Adherence to care for safe sleep & 4 & 1.5 & 2.7 \\
$\quad$ Others* & & & \\
Need for ongoing nurturing relationships & 20 & 7.6 & 54.1 \\
$\quad$ Effective bonding & 19 & 7.2 & 51.4 \\
$\quad$ Effective parent role & 264 & 100.0 & \\
Total & & & \\
\hline
\end{tabular}

Note: *nursing diagnoses that appeared only once: positive breastfeeding, suitable dilution of milk formula, effective eating pattern, effective breathing pattern.
The need for stable, supportive communities, and cultural continuity was observed only in one diagnosis, which reports the existence of problems related to the security in the community the family lived.

There were no identified diagnoses related to the need for experiences tailored to individual differences, developmentally appropriate experiences nor limit setting, structure and expectations.

Clinical and sociodemographic characteristics of the 37 newborns were analyzed regarding their association with wastage nursing diagnoses in view of the health-disease process, as shown in Table 3. However, it was verified that six medical records had no information on the presence of low birth weight $(<2,500 \mathrm{~g})$, four did not inform on the eventual hospitalization in the neonatal period, two would not inform on full term birth (gestational age $\geq 37$ weeks), two did not inform the type of delivery and one had no information on family composition.

Table 2 - Wastage nursing diagnoses in view of the health-disease process, according to the irreducible needs of children that correspond to it, São Paulo, Brazil, 2016

\begin{tabular}{|c|c|c|c|}
\hline $\begin{array}{l}\text { Nursing diagnoses that indicate wastage in view } \\
\text { of the health-disease process }\end{array}$ & $\begin{array}{l}\text { Frequency of the } \\
\text { diagnosis }(n)\end{array}$ & $\begin{array}{l}\text { \% of the diagno- } \\
\text { sis in total }\end{array}$ & $\begin{array}{l}\% \text { of children with } \\
\text { the diagnosis }\end{array}$ \\
\hline \multicolumn{4}{|l|}{ Need for physical and safety protection } \\
\hline Risk for suffocation & 15 & 13.9 & 40.5 \\
\hline Impaired tissue integrity & 14 & 13.0 & 35.1 \\
\hline Risk for fall & 11 & 10.2 & 29.7 \\
\hline Impaired hygiene of the umbilical cord stump & 8 & 7.4 & 21.6 \\
\hline Ineffective oral hygiene & 4 & 3.7 & 10.8 \\
\hline Impaired sleep & 4 & 3.7 & 10.8 \\
\hline Ineffective adherence to supplementation regime & 4 & 3.7 & 10.8 \\
\hline Impaired breastfeeding & 4 & 3.7 & 10.8 \\
\hline Impaired knowledge on therapeutic regime & 4 & 3.7 & 10.8 \\
\hline Risk for infant sudden death & 4 & 3.7 & 10.8 \\
\hline Interrupted breastfeeding & 3 & 2.8 & 8.1 \\
\hline Newborn colic & 3 & 2.8 & 8.1 \\
\hline Altered genital hygiene & 3 & 2.8 & 8.1 \\
\hline Ineffective adherence to the therapeutic regime (sunbathing) & 3 & 2.8 & 8.1 \\
\hline Impaired knowledge on oral care & 2 & 1.8 & 5.4 \\
\hline Impaired growth (insufficient weight gain) & 2 & 1.8 & 5.4 \\
\hline Impaired nutritional intake & 2 & 1.8 & 5.4 \\
\hline Risk for low weight & 2 & 1.8 & 5.4 \\
\hline Risk for interrupted breastfeeding & 2 & 1.8 & 5.4 \\
\hline Others* & 7 & 6.5 & 2.7 \\
\hline \multicolumn{4}{|l|}{ Need for ongoing nurturing relationships } \\
\hline Impaired family process & 3 & 2.8 & 8.1 \\
\hline Others** & 3 & 2.8 & 8.1 \\
\hline \multicolumn{4}{|l|}{ Need for stable and supporting communities } \\
\hline Inadequate house security & 1 & 0.9 & 2.7 \\
\hline Total & 108 & 100 & \\
\hline
\end{tabular}

Note: *nursing diagnoses that appeared more than once: adherence to care for ineffective safe sleep, impaired urinary elimination, heat rash, hematoma, impaired hygiene, infection perceived in left eye, risk for impaired development; **nursing diagnoses that appeared more than once: maternal fatigue, stress and insecurity. 
Table 3 - Association between clinical and sociodemographic variables of newborns and wastage nursing diagnoses in view of the health-disease process, São Paulo, 2016

\begin{tabular}{|c|c|c|c|c|}
\hline \multirow{2}{*}{$\begin{array}{l}\text { Clinical and sociodemographic } \\
\text { characteristics of newborns }\end{array}$} & \multicolumn{2}{|c|}{$\begin{array}{c}\text { Wastage nursing diagnoses } \\
\text { in view of the } \\
\text { health-disease process }\end{array}$} & \multirow{2}{*}{$\begin{array}{c}p \\
\text { value }\end{array}$} & \multirow{2}{*}{$\begin{array}{c}\text { Confidence } \\
\text { interval } \\
(95 \%)\end{array}$} \\
\hline & Yes $(n=31)$ & No $(n=6)$ & & \\
\hline Age in days (mean and standard deviation) & $14.3(6.2)$ & $20.1(5.6)$ & 0.03 & \\
\hline \multicolumn{5}{|l|}{ Gender } \\
\hline Female & $17(54.8 \%)$ & $2(33.3 \%)$ & 0.4 & {$[0.09-2.27]$} \\
\hline Male & $14(45.2 \%)$ & $4(66.7 \%)$ & & \\
\hline \multicolumn{5}{|l|}{ Type of delivery } \\
\hline Normal & $22(71 \%)$ & $3(50 \%)$ & 0.3 & {$[0.49-8.83]$} \\
\hline Cesarean section & $9(29 \%)$ & $3(50 \%)$ & & \\
\hline \multicolumn{5}{|l|}{ Low birth weight $(<2,500 \mathrm{~g})$} \\
\hline No & $27(96.4 \%)$ & $3(100 \%)$ & & \\
\hline Yes & $1(3.6 \%)$ & $0(0 \%)$ & 1 & [indefinido] \\
\hline \multicolumn{5}{|l|}{ Full term birth } \\
\hline No & $4(13.8 \%)$ & $0(0 \%)$ & 1 & [indefinido] \\
\hline Yes & $25(86.2 \%)$ & $6(100 \%)$ & & \\
\hline \multicolumn{5}{|l|}{ Neonatal hospitalization } \\
\hline No & $25(86.2 \%)$ & $4(100 \%)$ & & \\
\hline Yes & $4(13.8 \%)$ & $0(0 \%)$ & 1 & [indefinido] \\
\hline \multicolumn{5}{|l|}{ Family type } \\
\hline Nuclear or expanded & $27(87.1 \%)$ & $5(100 \%)$ & 1 & [indefinido] \\
\hline Single parent family & $4(12.9 \%)$ & $0(0 \%)$ & & \\
\hline
\end{tabular}

to adequate growth of the child $(25 \%)$, to adequate child development $(26 \%)$, to the adherence to the immunization regime $(10 \%)$, efficient evacuation $(12 \%)$ and adequate sleep $(12 \%)$.

In this study, the analysis of nursing diagnoses through the frame of reference of irreducible needs of children and social determination of the healthdisease process allowed us to verify that the health perspective that guides nurses in childcare has moved beyond biological aspects, even though these were the most frequent.

The need for physical protection and safety of the child is the one that mostly corresponds to the biological aspects and it is the most generally observed in health actions. Several researches $s^{(10,15,17)}$ highlight the identification of nursing diagnoses that are related to the need to offer protective environments against physical and physiological insults ${ }^{(7)}$, such as what was observed in this study, which matches newborns situation of absolute dependence on their caregivers regarding their physical and emotional well-being.

Among the diagnoses that indicate wastage, those related to the need for physical protection and safety also prevailed, and their relation

The data suggest that the lowest mean age was associated to the occurrence of wastage nursing diagnoses in view of the health-disease process. Other clinical and sociodemographic characteristics of newborns, such as gender, type of delivery, low birth weight, prematurity, hospitalization in neonatal period and family type showed no association with wastage nursing diagnoses.

\section{DISCUSSION}

The findings of this study showed that strengthening nursing diagnoses in view of the health-disease process had a lower diversity and an increased frequency when compared with wastage diagnoses. This finding demonstrates that the approach in the childcare nursing consultation privileged aspects to be praised and reinforced, also considering health problems situations. In addition, the results showed that wastage nursing diagnoses in view of health-disease process appeared with a frequency significantly higher in younger newborns.

The diagnoses that were related to potential strengthening of newborns, such as their efficient development, growth, evacuation, adequate sleep, exclusive breastfeeding and adherence to the immunization regime, were also the most frequent in other studies, as follows.

A study on consultations of children from zero to three years ${ }^{(10)}$ identified that the most frequent nursing diagnoses were those related with cultural and social factors involved in the families' ways of caring is observed. The diagnoses of risk for suffocation, present in $40.5 \%$ of these children, can be related to parent-infant cosleeping, to the use of objects in the crib and to the newborn lateral or ventral decubitus as a sleeping position.

In addition to accidental suffocation, previous studies show that several risk factors related to sudden infant death syndrome, such as prematurity, male gender, passive smoking, newborn overheating and ventral decubitus ${ }^{(18-19)}$. Studies performed in England ${ }^{(19)}$ and in the Unites States ${ }^{(20)}$ stressed the greater risk for sudden infant death in families in situation of social vulnerability, as well as the influence of parental behavioral aspects, such as the belief that the baby is not in risk when they practice co-sleeping, being their decision-making process guided by the perception of what would bring comfort to the child and make them sleep. Although the nurse should prevent accidental suffocation, promoting safe sleep practices, such as the guidance for the infant to sleep in a dorsal decubitus position, without blankets or other objects, in a crib with a firm mattress and in the parents' room ${ }^{(21)}$, it becomes crucial to consider the families' way of life, especially those in situation of social vulnerability, with scarce alternatives to the parent-infant co-sleeping.

The diagnosis of impaired tissue integrity, in this study, corresponded to the presence of diaper dermatitis and miliaria in 
babies and had similar prevalence to other studies with newborns. One of these studies identified that this diagnosis in $14.3 \%$ of hospitalized neonates in rooming-in ${ }^{(22)}$, and another in $11 \%$ of pre-terms in ambulatory monitoring ${ }^{(23)}$.

The diagnoses related to the need for ongoing nurturing relationship and stable and supportive communities, which were in the second position regarding frequency, show the apprehension of knowledge concerning the importance of interacting with the child, as well as supporting the family, as essential aspects related to child health.

A study ${ }^{(17)}$ that adopted the same frame of reference of irreducible needs showed that the facilitators of child safety for children under one year old include parents' presence and involvement, constant vigilance for physical and emotional protection, stimulating experiences of development, and supportive networks for the care of the child at home.

Nursing diagnoses that were related to the irreducible need for ongoing nurturing relationships, such as effective bonding and parent role, highlight that child health care implies to care for their development, understanding it as a phenomenon of continuity and change of biopsychological characteristics depending on reciprocal interaction processes of children with their context ${ }^{(7)}$. In this sense, a nursing consultation must strengthen families in the construction of their parenting, since, in the development process, children need positive interactions and proper care, performed by adults committed to their health and well-being ${ }^{(24)}$. The identification of such diagnoses in the scenario of this study points out to a larger view of child health care that can implement this strengthening of safe emotional interactions and promote healthy development of the child.

Although this expansion of the focus of care in the analyzed consultations is observed, the absence of diagnoses related to the need for experiences tailored to individual differences, developmentally appropriate experiences nor limit setting, structure and expectations is suggestive that there is still no incorporation of these aspects in newborns consultations.

\section{Study limitations}

Although this study analyzed data referring to 39 nursing newborn consultations and their families, some limitations include the small sample size and their unicentric character. Future researches expanding the number of families and their sociodemographic diversity can generate new evidence related to nursing diagnoses in childcare consultations of the newborn, as well as recognizing children's irreducible needs of a particular population.

Although the theoretical frame of reference of irreducible needs of children was not anchored in the collective health frame of reference, used in this study to classify the diagnoses in strengthening and wastage categories in view of the health-disease process, it is a specific frame of reference to child population, and it is considered that its use allowed to verify gaps that can be improved to reach completeness in newborn care. Future studies that considered both children's particularities and other aspects of social determination of the health-disease process may expand the understanding on the topic.

\section{Contributions to the field of Nursing}

Our study contributed to generate evidences regarding the adoption of a frame of reference specific to children in order to analyze nursing diagnoses that occurred in the clinical practice during consultations in the context of primary health care of the child. No studies were found that established a correlation between nursing diagnoses and the constructs of these irreducible needs of children's frame of reference. Our results demonstrated diagnoses related to the need for ongoing nurturing relationships, physical protection and safety, and stable and supportive communities.

The interpretation of nursing diagnoses according to the frame of reference of irreducible needs of children allows the nurse to plan care aiming to enrich the opportunities for the development of children's intellectual, emotional, social and physical skills in the home environment. The care that meet the needs for physical protection and safety, as well as for nurturing relationships, involve protective and safe environments, in addition to loving and empathetic interactions, so that the child feels loved and desired ${ }^{(7-9)}$. The experiences and opportunities of good relationships in the first years of life help to create a strong foundation, generating values, cognitive skills and sociability in future life. Therefore, the daily care of small children is fundamental for them to grow and develop to be physically healthy, emotionally safe and respected as social subjects ${ }^{(24)}$.

Considering the needs of each children and their families in their context of life, the nurse should seek to promote integral and integrated development, especially in the first three years of life, in order to improve family care practices. A expanded childcare clinic implies including sectors of early childhood education, social development and others so that it can act articulately with health professionals and with families to promote integral and integrated child development ${ }^{(25)}$.

Finally, the analysis of nursing diagnoses according to potential strengthening and wastage in view of the healthdisease process also favored the recognition of the healthdisease profile of the studied population, providing guiding elements of nursing care actions with newborns, their families and communities.

\section{CONCLUSION}

The most frequent nursing diagnoses were those related to strengthening in view of the health-disease process, such as the effective newborn development and growth. Nursing diagnoses indicating wastage were also present, especially risk for suffocation and impaired tissue integrity. The analysis of diagnoses according to the frame of reference of irreducible needs of children highlighted the need for physical protection and safety of newborns. Our results suggest that families are strengthened for newborn care, however there is a need for practices that strengthen family care and prevent child health problems. 


\section{REFERENCES}

1. World Health Organization-WHO. Global Health Observatory (GHO) data: neonatal mortality[Internet]. 2016[cited 20 Sep 2017]. Available from: http://www.who.int/gho/child_health/mortality/neonatal_text/en/

2. Lawn JE, Blencowe H, Oza S, You D, Lee AC, Waiswa P, et al. Every newborn: progress, priorities, and potential beyond survival. Lancet[Internet]. 2014[cited 2017 Nov 10];384(9938):189-205. Available from: http://www.thelancet.com/pdfs/journals/lancet/ PIIS0140-6736(14)60496-7.pdf

3. Brasil. Ministério da Saúde. Portal da Saúde. SIM - Sistema de Informações de Mortalidade[Internet]. Brasília: Ministério da Saúde; 2011 [cited 20 May 2015]. Available from: http://www2.datasus.gov.br/DATASUS/index.php?area $=060701$

4. Brasil. Ministério da Saúde. Secretaria de Atenção à Saúde, Departamento de atenção básica. Saúde da criança: crescimento e desenvolvimento[Internet]. Brasília: Ministério da Saúde; 2012[cited 2018 Aug 15]. 272 p. Available from: http://bvsms.saude.gov. $\mathrm{br} / \mathrm{bvs} /$ publicacoes/saude crianca crescimento desenvolvimento.pdf

5. Brasil. Conselho Federal de Enfermagem-Cofen. Resolução Cofen n 358, de 15 de outubro de 2009: Dispõe sobre a Sistematização da Assistência de Enfermagem e a implementação do Processo de Enfermagem em ambientes, públicos ou privados, em que ocorre o cuidado profissional de Enfermagem, e dá outras providências. Diário Oficial da União[Internet]. 2009 Oct 23[cited 2016 May 22];1:179. Available from: http://www.cofen.gov.br/resoluo-cofen-3582009_4384.html

6. Machado MFAS, Monteiro EMLM, Queiroz DT, Vieira NFC, Barroso MGT. Integrality, health professional education, health education and SUS proposals: a conceptual review. Ciênc Saúde Colet[Internet]. 2007[cited 2017 Dec 5];12(2):335-42. Available from: http:// www.scielo.br/pdf/csc/v12n2/a09v12n2.pdf

7. Veríssimo MLOR. The irreducible needs of children for development: a frame of reference to health care. Rev Esc Enferm USP[Internet]. 2018[cited 2018 Apr 5];51:e03283.. Available from: http://www.scielo.br/pdf/reeusp/v51/1980-220X-reeusp-S1980220X2017017403283.pdf

8. Brazelton TB, Greenspan SI. Why children need ongoing nurturing relationships. Early Child Today[Internet]. 2006 [cited 2018 Apr 5];21(1):14-5. Available from: https://eric.ed.gov/?id=EJ745704

9. Brazelton TB, Greenspan SI. The irreducible needs of children: what every child must have to grow, learn, and flourish. Cambridge: Perseus Publishing; 2000.

10. Luciano TS, Nóbrega MML, Saparolli ECL, Barros ALBL. Cross mapping of nursing diagnoses in infant health using the International Classification of Nursing Practice. Rev Esc Enferm USP[Internet]. 2014[cited 2017 Nov 6];48(2):250-6. Available from: http://www. scielo.br/pdf/reeusp/v48n2/pt_0080-6234-reeusp-48-02-250.pdf

11. Carvalho OMC, Silva KR, Andrade LZC, Silva VM, Lopes MVO. Prevalence of nursing diagnoses of breastfeeding in the motherinfant dyad in basic health unit. Rev Rene[Internet]. 2014[cited 10 Aug 2017];15(1):99-107. Available from: http://periodicos.ufc. br/rene/article/view/3090

12. Christoffel MM, Votto MG, Allevato CG, Ambrósio MDV, Araújo AS. Breastfeeding practices among postpartum women during nursing consultations in a primary health care center. Rev Min Enferm[Internet]. 2009[cited 2018 Aug 15];13(2):202-8. Available from: http://www.reme.org.br/artigo/detalhes/180

13. Secretaria Municipal de Assistência e Desenvolvimento Social de São Paulo. Coordenadoria do Observatório de Políticas Sociais. Atlas socioassistencial da cidade de São Paulo[Internet]. São Paulo: Coordenadoria do Observatório de Políticas Sociais; 2015[cited 2018 Aug 15]. 616 p. Available from: https://www.prefeitura.sp.gov.br/cidade/secretarias/upload/assistencia social/arquivos/ atlas_socioassistencial_sp_2015.pdf

14. Brasil. Ministério da Saúde. Secretaria de Vigilância em Saúde. Secretaria de Atenção à Saúde. Política Nacional de Promoção da Saúde. $3^{\text {a }}$ ed. Brasília: Ministério da Saúde; 2010. 60 p.

15. Chaves MMN, Farias FCSA, Apostólico MR, Cubas MR, Egry EY. Breastfeeding: nurses' practice under the perspective of the International Classification of Collective Health Nursing Practices. Rev Esc Enferm USP[Internet]. 2011[cited 2017 Oct 10];45(1):199205. Available from: http://www.scielo.br/pdf/reeusp/v45n1/28.pdf

16. Veríssimo MDLÓ, Sigaud CHS, Rezende MA, Ribeiro MO. O cuidado e as necessidades de saúde da criança. In: Fujimori E, Ohara CVS, (Eds.). Enfermagem e a saúde da criança na atenção básica. Barueri: Manole; 2009. p. 91-120.

17. Mello DF, Henrique NCP, Pancieri L, Veríssimo MLOR, Tonete VLP, Malone M. Child safety from the perspective of essential needs. Rev Latino-Am Enfermagem[Internet]. 2014[cited 2017 Aug 10];22(4):604-10 Available from: http://www.revistas.usp.br/ rlae/article/view/86671/89668

18. Psaila K, Foster JP, Pulbrook N, Jeffery HE. Infant pacifiers for reduction in risk of sudden infant death syndrome. Cochrane Database Syst Rev[Internet]. 2017[cited 2017 Sep 20];5(4):CD011147. Available from: http://onlinelibrary.wiley.com/doi/10.1002/14651858. CD011147/pdf

19. Bamber AR, Kiho L, Upton S, Orchard M, Sebire NJ. Social and behavioural factors in non-suspicious unexpected death in infancy; experience from metropolitan police project indigo investigation. BMC Pediatr[Internet]. 2016[cited 10 Dec 2017];16:6. Available 
from: https://www.ncbi.nlm.nih.gov/pmc/articles/PMC4711179/pdf/12887_2016_Article_541.pdf

20. Herman S, Adkins M, Moon RY. Knowledge and beliefs of African-American and American Indian parents and supporters about infant safe sleep. J Community Health[Internet]. 2015[cited 10 Dec 2017];40(1):12-9. Available from: https://www.ncbi.nlm.nih. gov/pmc/articles/PMC4382631/pdf/nihms673265.pdf

21. AAP Task Force on Sudden Infant Death Syndrome. SIDS and other sleep-related infant deaths: updated 2016 recommendations for a safe infant sleeping environment. Pediatrics[Internet]. 2016[cited 10 Dec 2017];138(5):e20162938. Available from: http:// pediatrics.aappublications.org/content/pediatrics/early/2016/10/20/peds.2016-2938.full.pdf

22. Inácio CCN, Chaves EMC, Freitas MC, Silva AVS, Alves AR, Monteiro AR. Nursing diagnoses in in-rooming units. Rev Bras Enferm[Internet]. 2010[cited 2017 Sep 5];63(6):894-9. Available from: http://www.scielo.br/pdf/reben/v63n6/04.pdf

23. Castro ACO, Duarte ED, Diniz IA. Nursing intervention to assisted children in outpatient tracking the risk of newborn. Rev Enferm Cent-Oeste Min[Internet]. 2017[cited 2017 Dec 10];7(1):e1159. Available from: http://www.seer.ufsj.edu.br/index.php/recom/ article/viewFile/1159/1320

24. Comitê Científico do Núcleo Ciência Pela Infância, (Ed.). Importância dos vínculos familiares na primeira infância: estudo II[Internet]. São Paulo: Fundação Maria Cecília Souto Vidigal; 2016[cited 2017 Dec 12]. 16 p. (Estudos do Comitê Científico NCPI; 2) Available from: http://www.mds.gov.br/webarquivos/arquivo/crianca_feliz/Treinamento_Multiplicadores_Coordenadores/WP_Vinculos \% 20 Familiares.pdf

25. Martins J, Santos MD, Veríssimo MLÓR, (Ed.). Formação em puericultura: práticas ampliadas. São Paulo: Fundação Maria Cecília Souto Vidigal; 2014. 88 p. (Programa São Paulo pela Primeiríssima Infância; Caderno 6) 